\title{
Lithium chloride corrects weakness and myopathology in a preclinical model of LGMD1D
}

Andrew R. Findlay, MD,* Rocio Bengoechea, PhD, * Sara K. Pittman, BS, Tsui-Fen Chou, PhD, Heather L. True, PhD, and Conrad C. Weihl, MD, PhD

Neurol Genet 2019;5:e318. doi:10.1212/NXG.0000000000000318
Correspondence

Dr. Findlay

arfindlay@wustl.edu

\section{Abstract}

\section{Objective}

To understand DNAJB6's function in skeletal muscle and identify therapeutic targets for limbgirdle muscular dystrophy 1D (LGMD1D).

\section{Methods}

DNAJB6 knockout (KO) myoblasts were generated with Crispr/cas9 technology, and differentially accumulated proteins were identified using stable isotope labeling, followed by quantitative mass spectrometry. Cultured KO myotubes and mouse muscle from DNAJB6b-WT or DNAJB6b-F93L mice were analyzed using histochemistry, immunohistochemistry, and immunoblot. Mouse functional strength measures included forelimb grip strength and inverted wire hang.

\section{Results}

DNAJB6 inactivation leads to the accumulation of sarcomeric proteins and hypertrophic myotubes with an enhanced fusion index. The increased fusion in DNAJB6 KO myotubes correlates with diminished glycogen synthase kinase- $\beta$ (GSK3 $\beta$ ) activity. In contrast, LGMD1D mutations in DNAJB6 enhance GSK3 $\beta$ activation and suppress $\beta$-catenin and NFAT3c signaling. GSK3 $\beta$ inhibition with lithium chloride improves muscle size and strength in an LGMD1D preclinical mouse model.

\section{Conclusions}

Our results suggest that DNAJB6 facilitates protein quality control and negatively regulates myogenic signaling. In addition, LGMD1D-associated DNAJB6 mutations inhibit myogenic signaling through augmented GSK3 $\beta$ activity. GSK3 $\beta$ inhibition with lithium chloride may be a therapeutic option in LGMD1D.

\footnotetext{
*These authors contributed equally to the manuscript.
}

From the Washington University School of Medicine (A.R.F., R.B., S.K.P., H.L.T., C.C.W); Department of Neurology (A.R.F., R.B., S.K.P., C.C.W), Hope Center for Neurological Diseases, St. Louis, MO; Harbor-UCLA Medical Center (T.-F.C.), Department of Pediatrics, Division of Medical Genetics, Torrance, CA; Department of Cell Biology and Physiology (H.L.T.), Saint Louis, MO.

Funding information and disclosures are provided at the end of the article. Full disclosure form information provided by the authors is available with the full text of this article at Neurology.org/NG.

The Article Processing Charge was funded by the authors.

This is an open access article distributed under the terms of the Creative Commons Attribution-NonCommercial-NoDerivatives License 4.0 (CC BY-NC-ND), which permits downloading and sharing the work provided it is properly cited. The work cannot be changed in any way or used commercially without permission from the journal. 


\section{Glossary}

CSA $=$ cross-sectional area; GFP = green fluorescent protein; GO = Gene Ontology; GSK3 $\beta=$ glycogen synthase kinase- $\beta$; HSP = heat shock protein; KO = knockout; LGMD1D = limb-girdle muscular dystrophy 1D; LC-MS/MS = Liquid chromatography with tandem mass spectrometry; NFATc3 = nuclear factor of activated T cells cytoplasmic 3; PBS = phosphate-buffered saline; SILAC = stable isotope labeling with amino acids in cell culture; WT $=$ wild type.

Protein chaperones, or heat shock proteins (HSPs), are increasingly recognized as critical for skeletal muscle health. ${ }^{1}$ Recently, mutations in DNAJB6, an HSP40 co-chaperone, were identified to cause limb-girdle muscular dystrophy $1 \mathrm{D}$ (LGMD1D), also known as LGMD D1 DNAJB6-related, a childhood- or adult-onset, dominantly inherited, progressive myopathy with vacuolar and aggregate myopathology. ${ }^{2-5}$ DNAJB6 is ubiquitously transcribed and mediates proper folding and disaggregation of proteins by HSP70. ${ }^{6,7}$ It has 2 isoforms: DNAJB6a, which localizes to the nucleus, and DNAJB6b, which localizes diffusely. ${ }^{4,8}$ In skeletal muscle, DNAJB6b localizes to the $\mathrm{Z}$ disc and is thought to be the isoform responsible for disease pathogenesis of LGMD1D. ${ }^{4,8}$ LGMD1D mutations in DNAJB6 reside within the G/F domain, a region important for client protein handling., ${ }^{4,8}$ DNAJB6's role in normal muscle and the pathomechanism of disease mutations is unknown.

In addition to its role in protein homeostasis, DNAJB6 also acts as a tumor suppressor through its interaction with glycogen synthase kinase- $\beta$ (GSK3 $\beta$ ). ${ }^{9,10}$ GSK3 $\beta$ activity is dependent on DNAJB6 chaperoning a multiprotein complex to maintain its dephosphorylated (active) state. ${ }^{10}$ Active GSK3 $\beta$ negatively regulates several myogenic signaling pathways, including $\beta$-catenin and nuclear factor of activated $\mathrm{T}$ cells cytoplasmic 3 (NFATc3) signaling. ${ }^{10-15}$ DNAJB6 has also been shown to directly interact with and inhibit NFATc3 transcriptional activity by recruiting class II histone deacetylases. ${ }^{16}$ In this study, we explored DNAJB6's role in skeletal muscle and its impact on myogenesis and related signaling pathways. We also investigated DNAJB6 disease mutation's impact on these pathways and their contribution to LGMD1D pathogenesis.

\section{Methods}

\section{Generation of DNAJB6 knockout (KO) C2C12 myoblasts}

DNAJB6 KO C2C12 cells were generated using 2 guide RNAs targeting 2 introns of $D N A J B 6$ to generate a $5.5-\mathrm{kb}$ outof-frame deletion (figure e-1A, links.lww.com/NXG/A147). We used this strategy to avoid modifying other DNAJ genes. Clones were screened for homozygosity of the $5.5-\mathrm{kb}$ deletion via sequencing (figure e-1B). Absence of DNAJB6 protein expression was confirmed via western blot (figure 1A).

\section{Antibodies}

Antibodies used were the following: anti-rabbit GAPDH (Cell Signaling, 2118), anti-rabbit desmin (Abcam, ab8592), anti- rabbit DNAJB6 (Abcam, ab75196), anti-rabbit $\alpha \beta$-crystallin (Enzo, ADI-SPA-223), anti-mouse hnRNPA2/B1 (Sigma, R4653), anti-rabbit alpha-actinin (Abcam ab68167), anti-mouse keratin 18 (Abcam, ab668), anti-rabbit GSK3 $\beta$-P(ser-9) (Cell Signaling, 9336), anti-rabbit GSK3 $\beta$ (Cell Signaling, 9315), antigoat FHL-1 (Abcam ab23937), and anti-mouse myosin (SigmaAldrich, M1570). Secondary antibodies include anti-mouse HRP (Pierce), anti-rabbit HRP (Cell Signaling), anti-goat HRP (Santa Cruz), and anti-mouse AlexaFluor (488).

\section{Western blot}

Muscle tissues and cultured cells were homogenized using RIPA lysis buffer (50 mM Tris- $\mathrm{HCl}, \mathrm{pH} 7.4,150 \mathrm{mM} \mathrm{NaCl}$, $1 \% \mathrm{NP}-40,0.25 \% \mathrm{Na}$-deoxycholate and $1 \mathrm{mM}$ EDTA) supplemented with protease inhibitor cocktail (Sigma-Aldrich), and lysates were centrifuged at $21380 \mathrm{~g}$ for 10 minutes. Protein concentrations were determined using a BCA protein assay kit (Thermo Fisher Scientific). Aliquots of lysates were solubilized in Laemmli buffer, and equal amounts of proteins were separated on $12 \%$ sodium dodecyl sulfate polyacrylamide gels. Proteins were transferred to nitrocellulose membrane, and the membrane was blocked with $5 \%$ nonfat dry milk in phosphate-buffered saline (PBS) with $0.1 \%$ Tween-20 for 1 hour. The membrane was then incubated with primary antibody, in $5 \%$ nonfat dry milk overnight at $4^{\circ} \mathrm{C}$, and then secondary antibody conjugated with horseradish peroxidase. Enhanced chemiluminescence (GH Healthcare, UK) was used for protein detection. Immunoblots were obtained using the G:BoxChemi XT4, Genesys Version 1.1.2.0 (Syngene). Densitometry was measured with ImageJ software (NIH).

\section{Cell culture}

HeLa cells were maintained in Dulbecco's Modified Eagle medium (DMEM, Gibco \#11965-084), 10\% fetal bovine serum (FBS, Atlanta Biologicals \#S10350H), and $50 \mu \mathrm{g} / \mathrm{mL}$ penicillin and streptomycin (P/S, Sigma \#P4333) at $37^{\circ} \mathrm{C}$ with $5 \% \mathrm{CO} 2 . \mathrm{C} 2 \mathrm{C} 12$ cells were maintained in proliferation media (DMEM with $20 \% \mathrm{FBS}, 50 \mu \mathrm{g} / \mathrm{mL} \mathrm{P} / \mathrm{S}$ ) and switched to differentiation media (DMEM with $2 \%$ horse serum, $50 \mu \mathrm{g} / \mathrm{mL}$ $\mathrm{P} / \mathrm{S}$ ) to form myotubes. Transfection of cells was performed with Lipofectamine 2000 (Life Technologies \#11668019) according to the manufacturer's instruction.

\section{Plasmid construction}

Mammalian constructs of DNAJB6b were cloned using sitedirected mutagenesis, digested with HindIII/XhoI, and ligated into vector pcDNA3.1 containing a green fluorescent protein (GFP) tag. DNAJB6b F89I and P96R mutations were generated with the Quik Change Mutagenesis Kit (Agilent Technologies \#200517). 


\section{Immunofluorescence}

$\mathrm{C} 2 \mathrm{C} 12$ cells were grown, stained, and imaged directly on cell culture plastic. Cells were washed 3 times with PBS, fixed in $4 \%$ PFA for 10 minutes, permeabilized with $0.1 \%$ Triton X-100 in PBS for 10 minutes, and then blocked with 3\% BSA in PBS for 30 minutes to 1 hour at room temperature. Cells were stained with primary antibody (anti-mouse myosin) at $4^{\circ} \mathrm{C}$ overnight, followed by washing 3 times with PBS. Cells were incubated with Alexa 488 Fluor-conjugated secondary antibody at RT for 1 hour and mounted with Mowiol media containing 4',6diamidino-2-phenylindole. $\mathrm{C} 2 \mathrm{C} 12$ differentiation experiments were performed in triplicate. Fusion index was determined as a ratio of nuclei number within multinucleated myosin-positive myotubes to the total number of nuclei. Nuclei were counted from 10 random fields taken with $10 \times$ objective equipped in a NIKON Eclipse 80i fluorescence microscope. Myosin stained myotubes with irregular staining pattern were counted and divided by the total number of myosin-positive myotubes to quantify the percent of myotubes with irregular myosin staining.

\section{Electron microscopy}

$\mathrm{C} 2 \mathrm{C} 12$ cells were differentiated for 6 days, rinsed briefly in PBS, and fixed immediately with Karnovsky fixative at $4^{\circ} \mathrm{C}$ for 24 hours. Fixed myotubes were embedded in plastic and sectioned for imaging with a JEOL JEM-1400 Plus $120 \mathrm{kV}$ Transmission Electron Microscope equipped with an AMT XR111 high-speed $4 \mathrm{k} \times 2 \mathrm{k}$ pixel phosphor-scintillated 12-bit charge coupled device camera.

\section{Stable isotope labeling by amino acids and mass spectrometry}

For "forward" stable isotope labeling with amino acids in cell culture (SILAC) experiments, $\mathrm{KO}$ C2C12 cells were cultured in "heavy" media in which Arg and Lys were replaced by ${ }^{13} \mathrm{C}_{6}$ Arg and ${ }^{13} \mathrm{C}_{6},{ }^{15} \mathrm{~N}_{2}$-Lys, whereas C2C12 DNAJB6 wild-type (WT) cells were grown in "light" media containing ${ }^{12} \mathrm{C}_{6}$-Arg and ${ }^{12} \mathrm{C}_{6},{ }^{14} \mathrm{~N}_{2}$-Lys (Thermo Fisher). For "reverse" experiments, DNAJB6 KO C2C12 cells were grown in "light" media and WT $\mathrm{C} 2 \mathrm{C} 12$ cells were grown in "heavy" media. Two biological replicates were used for each condition. Myoblasts were passaged 6 times to allow for sufficient incorporation of label. For mass spectrometry analyses, we used the same methodology as the one used in previous studies with minor modification. ${ }^{17,18}$ Briefly, total cell lysate was generated using $9 \mathrm{M}$ Urea in $20 \mathrm{mM}$ HEPES, $\mathrm{pH} 8.0$ containing protease inhibitor and phosphatase inhibitor tablets. Equal amount $(0.3 \mathrm{mg})$ for each cell type was mixed and digested using Lys-C and trypsin digestion protocol as described. ${ }^{17,18}$ The peptides were loaded onto an Easy Nano-LC Q-Exactive Orbitrap, and the peak lists were generated using Proteome Discoverer software (Thermo Fisher Scientific). ${ }^{18}$ Only proteins that were present in all biological replicates in both forward and reverse SILAC experiments were considered for further data analysis. Proteins were considered increased in DNAJB6 KO C2C12 cells if there was at least a 1.5-fold change in forward $\mathrm{KO} / \mathrm{WT}$ experiments and a 0.6 -fold change in reverse $\mathrm{WT} / \mathrm{KO}$ experiments. Proteins were considered decreased in DNAJB6 KO C2C12 cells if there was at least a 0.6-fold change in forward $\mathrm{KO} / \mathrm{WT}$ experiments and a 1.5fold change in reverse $\mathrm{WT} / \mathrm{KO}$ experiments.

\section{Ontological analysis}

All differentially expressed proteins were classified broadly into several catalogs according to the Gene Ontology (GO) annotation (geneontology.org). Overrepresentation analyses of GO terms, including biological process, molecular function, and cellular component, were performed using the ConsensusPathDB-human database system (cpdb.molgen. mpg.de/CPDB), which is a molecular functional interaction database. All proteins detected in SILAC experiments were used as background for comparison. The GO level 2 and 3 categories and a $p$ value cutoff of 0.01 were selected.

\section{Luciferase assays}

C2C12 myoblasts were transfected with 20 ng Renilla control reporter (pRL-TK) and either $1 \mu \mathrm{g}$ of the $\beta$-catenin luciferase reporter (TOPflash, Addgene plasmid \#12456) or $1 \mu \mathrm{g}$ of an NFAT-sensitive luciferase reporter (pGL3-NFAT luciferase, Addgene plasmid \#17870).

HeLa cells were transfected with $0.5 \mu \mathrm{g}$ of GFP control or GFPtagged DNAJB6b construct, 20 ng Renilla control reporter, and either $0.5 \mu \mathrm{g}$ of the $\beta$-catenin luciferase reporter or $0.5 \mu \mathrm{g}$ of an NFAT-sensitive luciferase reporter. For $\beta$-catenin luciferase experiments, HeLa cells were treated with $20 \mathrm{mM}$ lithium chloride (LiCl) (Sigma-Aldrich 203637) for 12 hours before measuring luminescence to stimulate $\beta$-catenin transcriptional activity. For NFATc3 luciferase experiments, HeLa cells were transfected with $0.5 \mu \mathrm{g}$ of plasmid encoding NFATc3 to stimulate transcriptional activity ( $\mathrm{pBS}$ mNFATc3-EE, Addgene plasmid \#17868). Cells were lysed, and luciferase activities were measured using the Dual-Glo luciferase kit (Promega E2920) and a microplate luminometer (BioTek Instruments). Lysates $(75 \mu \mathrm{L})$ were pipetted into 96-well plates in triplicate. Data were calculated as luciferase/Renilla signal. Fold change was calculated based on change from unstimulated baseline (e.g., LiCl treated vs untreated or NFATc3 transfected vs control transfected).

\section{Animal studies}

\section{Animal and experimental protocols}

Transgenic human-V5-DNAJB6b mice with $M C K$ promoter were previously generated. ${ }^{8}$ DNAJB6b-F93L mice develop a prominent myopathy and are weak by age 3 months. ${ }^{8}$ Mice were housed in a temperature-controlled environment with 12-hour light-dark cycles and received food and water ad libitum. Mice were killed, and skeletal muscle was dissected. For western blot analysis, muscle was flash frozen in liquid nitrogen and stored at $-80^{\circ} \mathrm{C}$.

\section{Wire screen holding and grip test}

Grip strength testing consisted of 5 separate measurements using a trapeze bar attached to a force transducer that recorded peak- 
Figure 1 DNAJB6 knockout results in accumulation of sarcomeric proteins and altered myofibrillogenesis

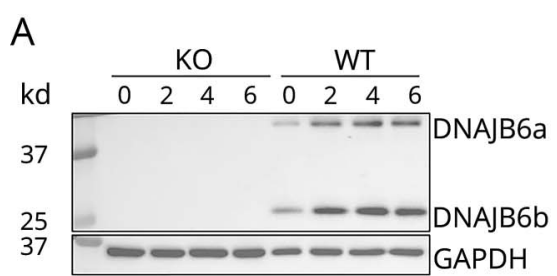

D

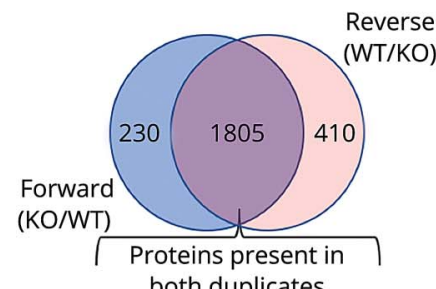
both duplicates

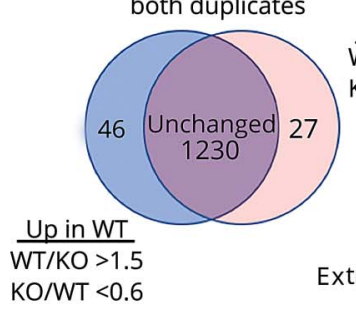

KO/WT $<0.6$ $\mathrm{NADH}$ dehydrogen

$\frac{\mathrm{W} \operatorname{Tin} K \mathrm{KO}<0.6}{\mathrm{KO} / \mathrm{WT}>1.5}$ KO/WT $>1.5$

Carbohydrate binding

Laminin complex
Laminalar structure organization

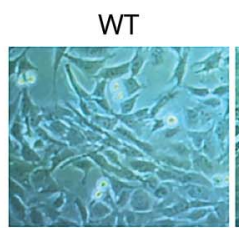

DNAJB6 KO

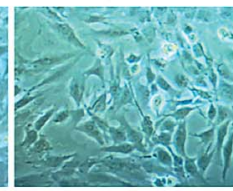

C.

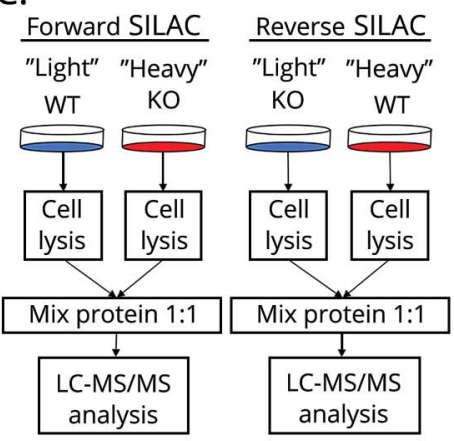

E. Ontology of protiens increased in kO cells

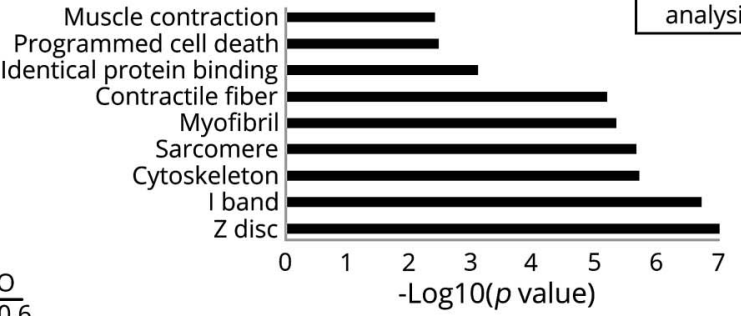

F. Ontology of proteins decreased in KO cells

Electron transport chain

Collagen catabolic process
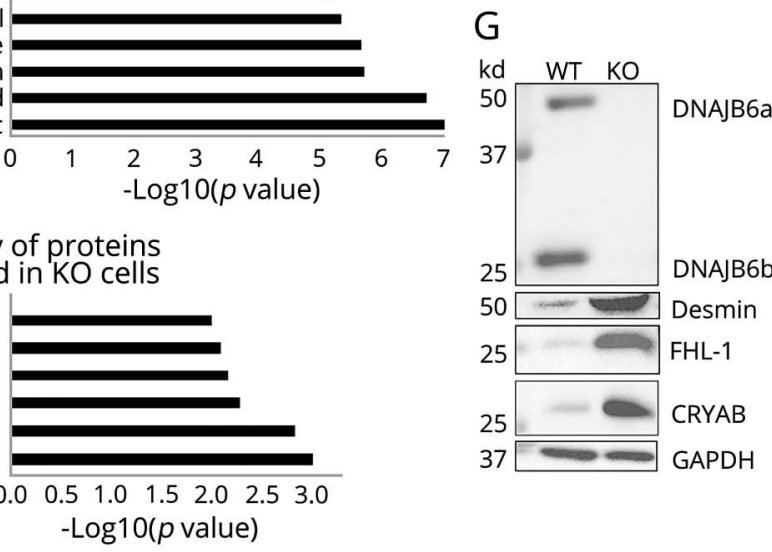

GAPDH

$\mathrm{H}$

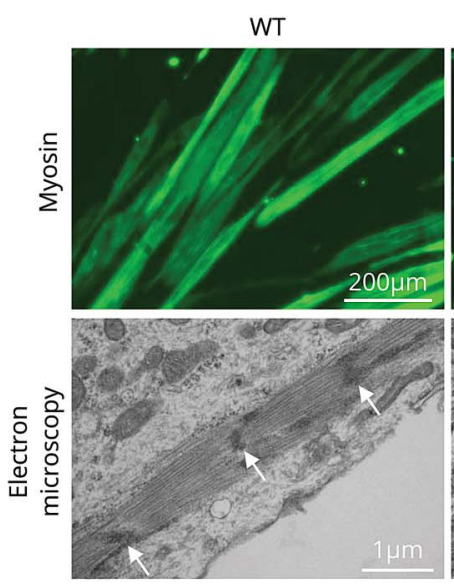

DNAJB6 KO

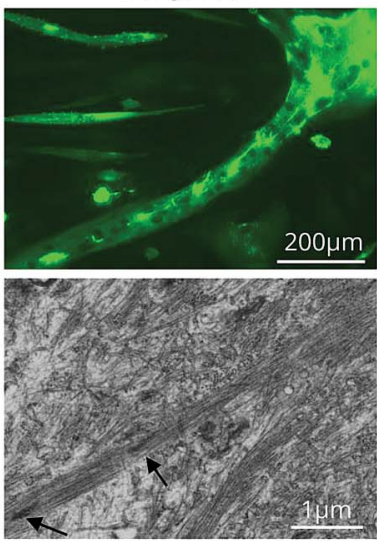

I. Myofibrillar disorganization

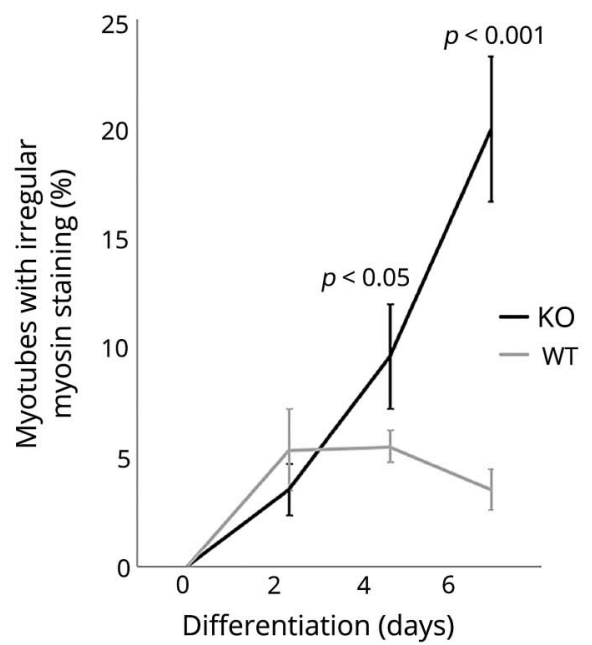

(A) Western blot demonstrating the absence of both DNAJB6 isoforms in Crispr/Cas9-generated DNAJB6 KO C2C12 myoblasts and during differentiation into myotubes. (B) Bright-field image demonstrating normal morphology of DNAJB6 KO myoblasts. (C) Flowchart of forward and reverse SILAC labeling combined with LC-MS/MS for comparative analysis of protein expression in WT and DNAIB6 KO myoblasts. (D) Quantitation overlap of the detected proteins in the 2 forward and 2 reverse SILAC labeling experiments and those that differentially accumulated in WT vs DNAJB6 KO C2C12 cells. (E) Ontological analysis of proteins increased in DNAJB6 KO myoblasts. (F) Ontological analysis of proteins decreased in DNAJB6 KO myoblasts. (G) Western blot of WT and KO myoblasts confirming increased levels of several proteins identified in SILAC analysis. (H) Differentiation of KO myoblasts into myotubes reveals altered myofibrillar organization on myosin staining and electron microscopy. White arrows demonstrate Z discs in WT myotubes with well-organized sarcomeres. Dark arrows demonstrate Z discs in KO myotubes with poor myofibrillar organization. (I) Quantitation of myotubes with irregular myosin staining. Error bars represent the standard error of 3 independent experiments. $\mathrm{KO}=$ knockout; LC-MS/MS = liquid chromatography with tandem mass spectrometry; SILAC = stable isotope labeling with amino acids in cell culture; WT = wild type. 
Table Increased proteins in DNAJB6 KO myoblasts

\begin{tabular}{|c|c|c|}
\hline Gene & Protein & $\begin{array}{l}\text { KO/WT } \\
\text { average }\end{array}$ \\
\hline *PDLIM3 & PDZ and LIM domain protein 3 & 6.89 \\
\hline PTGIS & Prostacyclin synthase & 4.30 \\
\hline *ACTN3 & Alpha-actinin-3 & 4.22 \\
\hline SERPINB9B & Serpin B9 & 3.99 \\
\hline TPPP3 & $\begin{array}{l}\text { Tubulin polymerization-promoting } \\
\text { protein family member } 3\end{array}$ & 3.30 \\
\hline FTL1 & Ferritin light chain 1 & 3.24 \\
\hline NAPA & $\begin{array}{l}\text { Alpha-soluble NSF attachment } \\
\text { protein }\end{array}$ & 3.16 \\
\hline *CRYAB & Alpha-crystallin B chain & 3.00 \\
\hline *AKAP12 & $\begin{array}{l}\text { Isoform } 2 \text { of A-kinase anchor } \\
\text { protein } 12\end{array}$ & 2.92 \\
\hline$R P L 14$ & 605 ribosomal protein L14 & 2.69 \\
\hline EXOC1 & Exocyst complex component 1 & 2.42 \\
\hline *FHL1 & Four and a half LIM domains protein 1 & 2.34 \\
\hline SGPL1 & Sphingosine-1-phosphate lyase 1 & 2.26 \\
\hline *JUP & Junction plakoglobin & 2.18 \\
\hline PAK2 & Serine/threonine protein kinase PAK 2 & 2.13 \\
\hline DNM1L & Isoform 4 of dynamin-1-like protein & 2.09 \\
\hline *DES & Desmin & 2.05 \\
\hline TUBB3 & Tubulin beta-3 chain & 1.97 \\
\hline GAA & Lysosomal alpha-glucosidase & 1.96 \\
\hline UGP2 & $\begin{array}{l}\text { Isoform } 2 \text { of UTP_glucose-1- } \\
\text { phosphate uridylyltransferase }\end{array}$ & 1.95 \\
\hline CTSL & Cathepsin L1 & 1.86 \\
\hline *DNAJB4 & DnaJ homolog subfamily B member 4 & 1.83 \\
\hline *HSPB1 & Isoform B of heat shock protein beta-1 & 1.82 \\
\hline MVP & Major vault protein & 1.81 \\
\hline$A B R A C L$ & Costars family protein ABRACL & 1.80 \\
\hline *PDLIM1 & PDZ and LIM domain protein 1 & 1.78 \\
\hline$K L C 2$ & Kinesin light chain 2 & 1.75 \\
\hline
\end{tabular}

Abbreviations: $\mathrm{KO}=$ knockout; SILAC $=$ stable isotope labeling with amino acids in cell culture; $\mathrm{WT}=$ wild type.

Note the many sarcomeric and chaperone proteins increased in DNAJB6 KO myoblasts ( ${ }^{*}$ and bold). Proteins meeting SILAC threshold of KO/WT ratio of $>1.5$ and WT/KO ratio of $<0.6$.

generated force while mice were pulled backward by their tail (Stoelting, Wood Dale, IL). The resulting measurement was recorded, and the average of the highest 3 measurements was determined to give the strength score. Another quantitative strength measurement was performed by wire screen holding test. Mice were placed on a grid where it stood using all 4 limbs. Subsequently, the grid was inverted $15 \mathrm{~cm}$ above a cage. Latency for the mouse to release the mesh is recorded, and the average hanging time of 3 trials was used.

\section{Histochemistry}

Isolated muscle was mounted using tragacanth gum (Sigma, G1128) and quick frozen in liquid nitrogencooled 2-methylbutane. Samples were stored at $-80^{\circ} \mathrm{C}$ until sectioning into $10-\mu \mathrm{m}$ sections. Hematoxylin and eosin staining was performed as previously described. ${ }^{19}$ Images were taken with a 5-megapixel color charge coupled device (Nikon, Tokyo, Japan), and the muscle fiber cross-sectional area (CSA) was measured using ImageJ software. Two separate individuals, blinded to the treatment status of mice, took photographs and measured the CSA. Four representative images from each animal's tibialis anterior were used to determine the average crosssectional area.

\section{Lithium treatment}

After oxygen exposure, mice were anesthetized with isofluorane and injected intraperitoneally with $\mathrm{LiCl}(250 \mathrm{mg} / \mathrm{kg}$ body weight; Sigma-Aldrich) or dimethyl sulfoxide daily for 1 month.

\section{Statistical analysis}

Results are presented as mean and standard error of the mean. Statistical analyses were performed using paired $t$ tests.

\section{Standard protocol approvals, registrations, and patient consents}

All animal experimental protocols were approved by the Animal Studies Committee of Washington University School of Medicine.

\section{Data availability policy}

The supplementary data can be accessed via links.lww.com/ NXG/A145 and links.lww.com/NXG/A147. The authors will share the data of this study by request from any qualified investigator. Any data not published within the article are available in a public repository and will be shared by request from any qualified investigator.

\section{Results}

\section{DNAJB6 KO myoblasts accumulate sarcomeric proteins and form altered myofibrillar structures}

To understand DNAJB6's role in skeletal muscle, we generated $\mathrm{C} 2 \mathrm{C} 12$ myoblasts that lack both isoforms of DNAJB6 (DNAJB6a and DNAJB6b) using CRISPR/cas9 technology (figure 1A). These undifferentiated cells were viable and morphologically similar to control C2C12 cells (figure 1B). To identify differentially accumulated proteins, we performed SILAC. SILAC experiments were conducted in duplicate, including 2 forward (KO/WT) and 2 reverse labeling (WT/ $\mathrm{KO}$ ) of control and DNAJB6 KO C2C12 myoblasts (figure 1C depicts the setup for SILAC-based proteomics). Using 
A

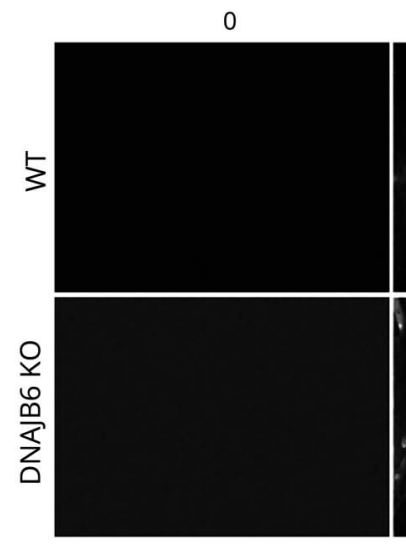

B. Fusion index

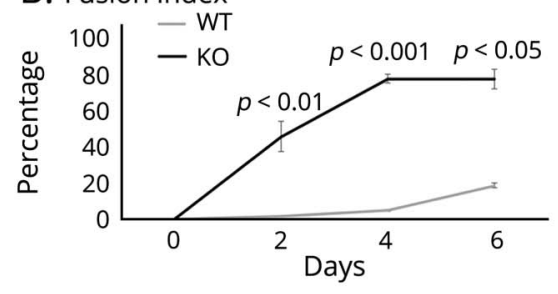

D. TOPFLASH

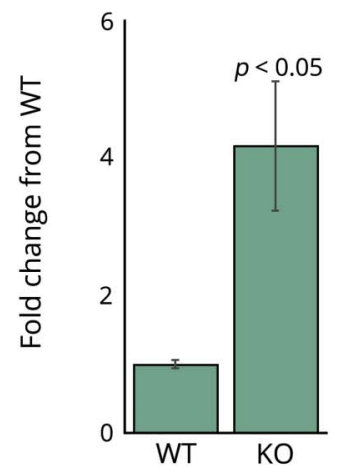

Day

2

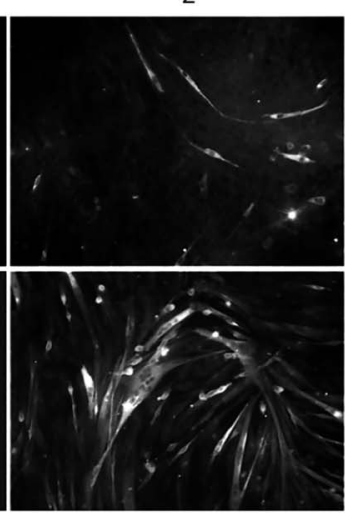

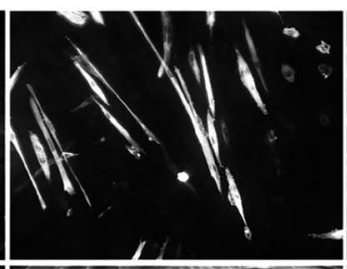

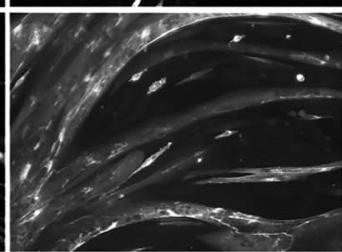

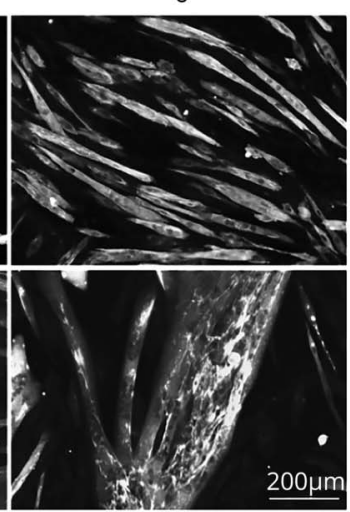

C

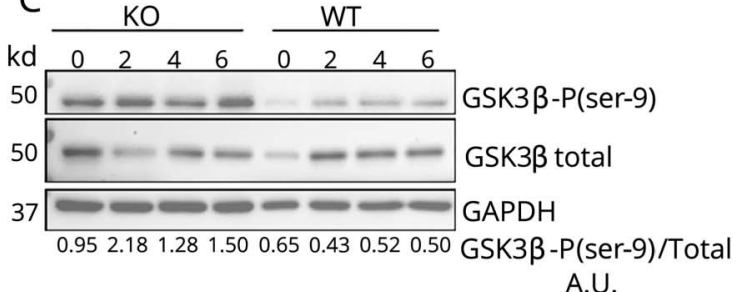
A.U.

E. NFATC3

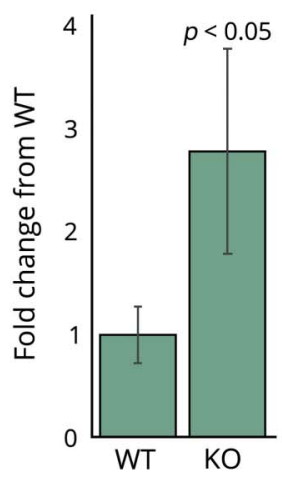

(A) C2C12 WT and DNAJB6 KO myoblasts differentiated into myotubes for 6 days and stained for myosin. DNAJB6 KO myoblasts fused to form large myotubes with enhanced fusion index (B). Error bars represent the standard error of 3 independent experiments. (C) Western blot confirmed increased inactive GSK3 $\beta$ $\mathrm{P}($ ser-9) in KO myoblasts. GSK3 $\beta-P($ ser-9)/GSK3 $\beta$-total ratio is given below western blot. (D) Increased $\beta$-catenin transcriptional activity in DNAJB6 KO myoblasts compared with WT myoblasts measured by TOPFLASH luciferase assay. (E) Increased NFATc3 transcriptional activity in DNAJB6 KO myoblasts compared with WT myoblasts. Error bars represent the standard error of at least 2 independent experiments. GSK3 $\beta=$ glycogen synthase kinase- $\beta$; KO = knockout; NFATc3 = nuclear factor of activated T cells cytoplasmic 3; WT = wild type.

liquid chromatography with tandem mass spectrometry analysis, we quantified 2035 proteins in the 2 forward experiments, 2215 proteins in the 2 reverse experiments, and a total of 2445 distinct proteins overall (figure 1D). Nearly $75 \%$ of the proteins quantified were present in both forward and reverse experiments (figure 1D). For subsequent data analysis, we used only proteins present in both duplicates of the forward and reverse experiments (figure 1D). To identify proteins that accumulate in DNAJB6 KO cells, we used 2 thresholds: a 1.5-fold change in forward $\mathrm{KO} / \mathrm{WT}$ experiments and a 0.6-fold change in reverse $\mathrm{WT} / \mathrm{KO}$ experiments. Based on these criteria, 27 proteins were identified (figure 1D, table
1). Ontological analysis of the 27 proteins increased in $\mathrm{KO}$ cells identified categories such as sarcomere, $\mathrm{Z}$ disc, and muscle contraction (figure $1 \mathrm{E}$ ). Notably, these proteins included several Z-disc proteins such as desmin, $\boldsymbol{\alpha}$-actinin, FHL-1, and PDZ-Lim domain proteins 1 and 3. It also identified the co-chaperone DNAJB4 and small HSPs HSPB1 and HSPB5 ( $\alpha \beta$-crystallin). Reversal of thresholds to identify proteins decreased in DNAJB6 KO cells identified 46 proteins belonging to several ontological categories including laminin complex and collagen catabolic process (figure 1, D and F, table e-1, links.lww.com/NXG/A145). Immunoblotting of lysates from control and DNAJB6 KO 


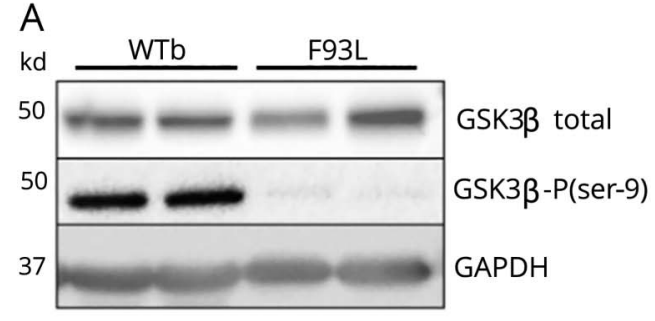

C. TOPFLASH luciferase activity

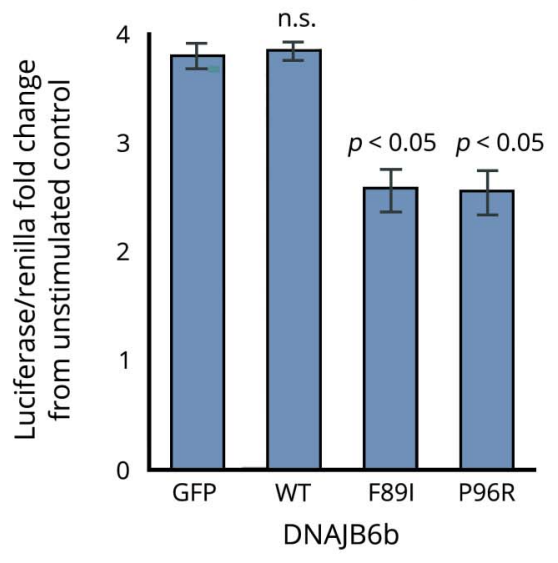

E

(Inactive)
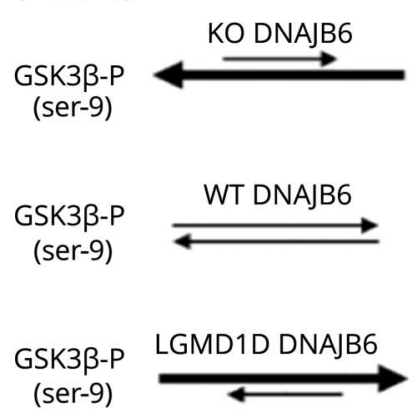

(Active)

GSK3 $\beta$

GSK3 $\beta$

GSK3 $\beta$

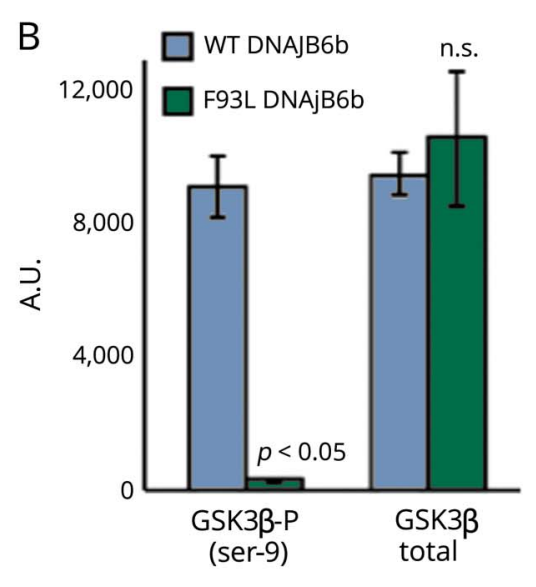

D. NFATC3 luciferase activity
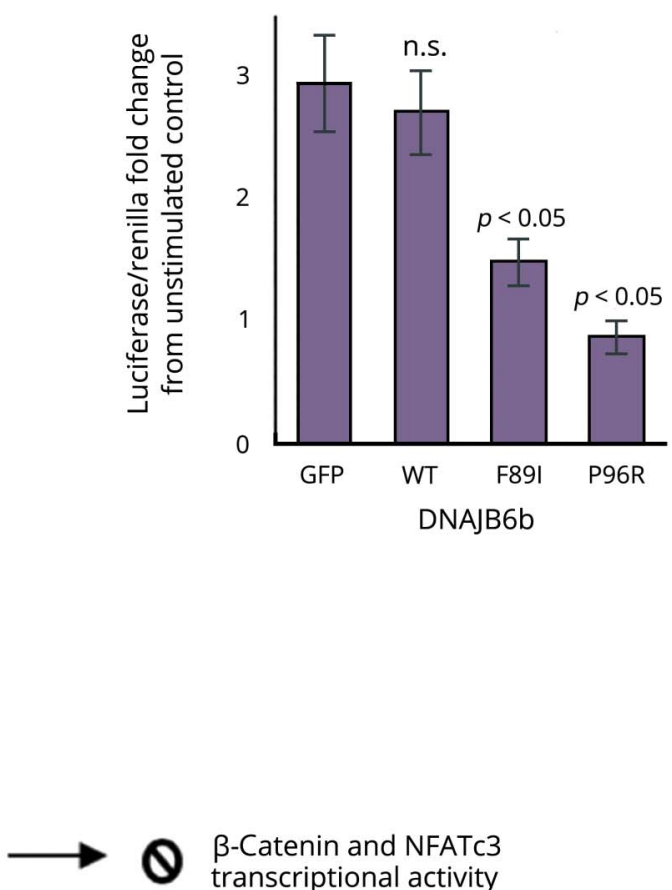

$\beta$-Catenin and NFATC3

transcriptional activity

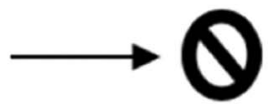

$\beta$-Catenin \& NFATC3

transcriptional activity

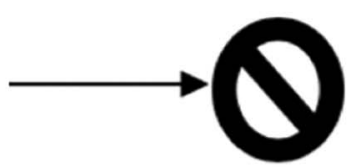

B-Catenin \& NFATC3 transcriptional activity
(A) Western blot of skeletal muscle lysates from 3-month old LGMD1D mutant mice (F93Lb, $n=2$ ) vs control (WTb, $\mathrm{n}=2$ ) demonstrating significantly reduced inactive GSK3 $\beta$ $\mathrm{P}($ ser-9) in mutant mice. Error bars represent the standard error. (B) Quantitation of western blot. Dualluciferase assay demonstrating reduced $\beta$-catenin (C) and NFATC3 (D) transcriptional activity in HeLa cells transfected with mutant DNAJB6b constructs compared with unstimulated controls. $\beta$-catenin transcriptional activity was stimulated via treatment with $20 \mathrm{mM} \mathrm{LiCl}$ for 12 hours. NFATc3 transcriptional activity was stimulated by overexpression of NFATC3 via transient transection. Error bars in C and D represent the standard error from 3 separate experiments. (E) Proposed model for DNAJB6's spectrum of impact on GSK3 $\beta$ activation and myogenesis. GSK3 $\beta=$ glycogen synthase kinase- $\beta$; LGMD1D = limbgirdle muscular dystrophy 1D: NFATC3 $=$ nuclear factor of activated T cells cytoplasmic $3 ; \mathrm{WT}=$ wild type. myoblasts for several of these proteins confirmed their accumulation (figure 1G). Skeletal muscle from LGMD1D mice similarly demonstrates an accumulation of several of these Z-disc proteins. ${ }^{8}$ When differentiated into myotubes, DNAJB6 KO cells contained abnormal myofibrillar structures characterized by irregular myosin immunofluorescence and disorganized sarcomere organization on electron microscopy (figure $1, \mathrm{H}$ and I). Overall, this suggests that the absence of DNAJB6 leads to impaired organization and accumulation of sarcomeric proteins. These findings are similar to the myofibrillar abnormalities noted in mouse and human LGMD1D skeletal muscle. ${ }^{3,8}$ 
A

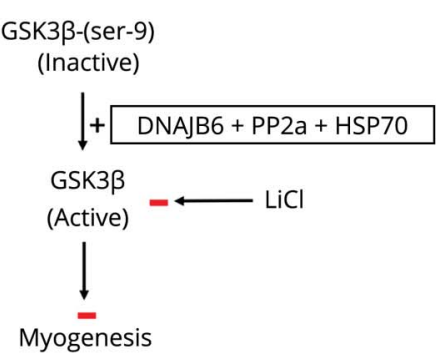

B

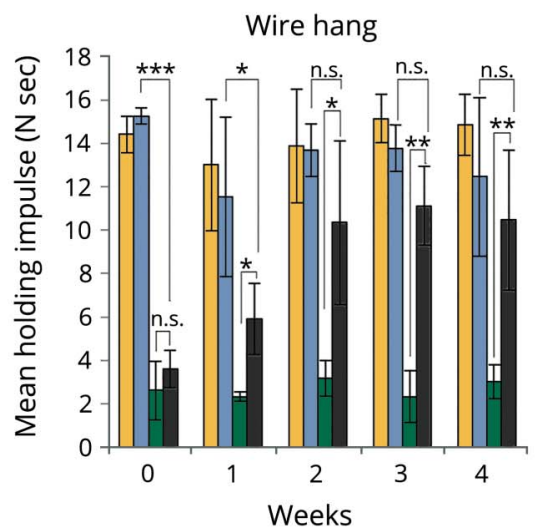

$\square$ WTB NT $\square$ F93L NT

$\square$ WTB LiCl $\square \mathrm{F93I} \mathrm{LiCl}$

Grip strength

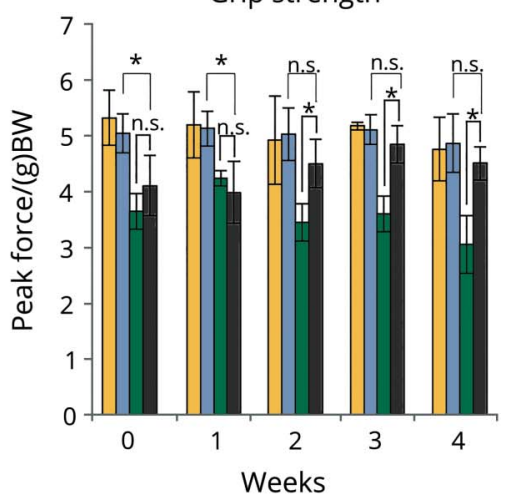

(A) Diagram demonstrating DNAJB6's role in chaperoning the dephosphorylation of GSK3 $3-\mathrm{P}(\mathrm{ser}-9)$ and treatment strategy with GSK3 inhibitor, LiCl. (B) Functional testing (wire hang and grip strength) of 3-month-old DNAJ6b-WT and DNAJB6b-F93L mice treated daily with LiCl vs no treatment (NT). Two independent experiments were performed for a total of 8 mice per condition. Strength of DNAJB6b-F93L mice treated with LiCl significantly improves over the

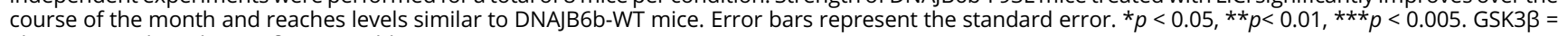
glycogen synthase kinase- $\beta$; WT = wild type.

\section{KO of DNAJB6 in myoblasts impairs GSK3 $\beta$ activation and enhances myogenesis}

When differentiated for 6 days, C2C12 myoblasts form myotubes with a fusion index (nuclei contained in myotubes/total nuclei) of approximately $20 \%$ (figure 2, A and B). Surprisingly, we found that DNAJB6 KO myotubes have an enhanced fusion index (77\%) and form enlarged myotubes (figure 2, A and B). This suggested that DNAJB6 may play a role in myogenic signaling pathways. DNAJB6 is known to chaperone the dephosphorylation (activation) of GSK $3 \beta$, an important signaling kinase that suppresses several myogenic signaling pathways. ${ }^{10,14,15,20}$ Compared with WT, DNAJB6 KO myoblasts and myotubes contained increased levels of phosphorylated (inactive) GSK3 $\beta-\mathrm{P}($ ser-9) (figure 2C). This suggests that the absence of DNAJB6 is associated with impaired $\operatorname{GSK} 3 \beta-\mathrm{P}($ ser-9) dephosphorylation and supports DNAJB6's proposed role in GSK3 $\beta$ activation. ${ }^{10}$ GSK $3 \beta^{\prime}$ s impact on myogenesis is thought to be mediated through suppression of $\beta$-catenin and NFATc3 signaling. ${ }^{13-15}$ We therefore evaluated $\beta$-catenin and NFATc3 transcriptional activity using dual luciferase assays. We found that both NFATc3 and $\beta$-catenin transcriptional activity were increased in DNAJB6 $\mathrm{KO}$ myoblasts (figure 2, D and E). These findings suggest that the enlarged myotubes and enhanced fusion index resulting from loss of DNAJB6 may be related to impaired GSK3 $\beta$ $\mathrm{P}($ ser-9) dephosphorylation and increased $\beta$-catenin and NFATc3 transcriptional activity.

\section{LGMD1D mutations enhance GSK3 $\beta$ dephosphorylation in skeletal muscle}

We next investigated the impact of dominant DNAJB6 disease-causing mutations on GSK $3 \beta^{\prime}$ s phosphorylation state in muscle. We used skeletal muscle lysate from 3-month-old LGMD1D model mice that express a V5tagged DNAJB6b-F93L transgene and control mice that express a DNAJB6b-WT transgene. ${ }^{8}$ Of interest, we found a near complete absence of $\operatorname{GSK} 3 \beta-\mathrm{P}($ ser-9) in the LGMD1D mice (figure $3, \mathrm{~A}$ and $\mathrm{B}$ ). This suggested that DNAJB6 disease mutations increase GSK3 $\beta$ dephosphorylation to its active state. We next evaluated the impact of DNAJB6 mutations on myogenic signaling pathways downstream of GSK3 $\beta$. We used a dual luciferase assay to measure $\beta$-catenin and NFATc3 transcriptional activity in HeLa cells transfected with GFP-tagged DNAJB6 constructs. We treated cells with $20 \mathrm{mM} \mathrm{LiCl}$, a GSK3 $\beta$ inhibitor, to stimulate $\beta$-catenin transcriptional activity (figure $3 \mathrm{C}$ ). We overexpressed NFATc3 via transient transfection of cells to stimulate NFATc3 transcriptional activity. We found that both $\beta$-catenin and NFATc3 transcriptional activity were suppressed by the presence of various DNAJB6 mutants (figure 3, C and D).

These findings illustrate DNAJB6's spectrum of impact on GSK3 $\beta^{\prime}$ 's activity: absence of DNAJB6 is associated with impaired dephosphorylation of GSK3 $\beta-\mathrm{P}($ ser-9), whereas dominant disease-causing mutations in DNAJB6 enhance dephosphorylation GSK3 $\beta-\mathrm{P}($ ser-9) to its active form (figure 3E).

\section{GSK3 $\beta$ inhibitor LiCl improves strength, muscle mass, and histopathology in LGMD1D mice}

To test the therapeutic potential of GSK $3 \beta$ inhibition (figure $4 A$ ), we treated 3-month-old control mice overexpressing DNAJB6b-WT and mutant mice overexpressing DNAJB6bF93L with either vehicle (dimethyl sulfoxide) or $\mathrm{LiCl}$ via 

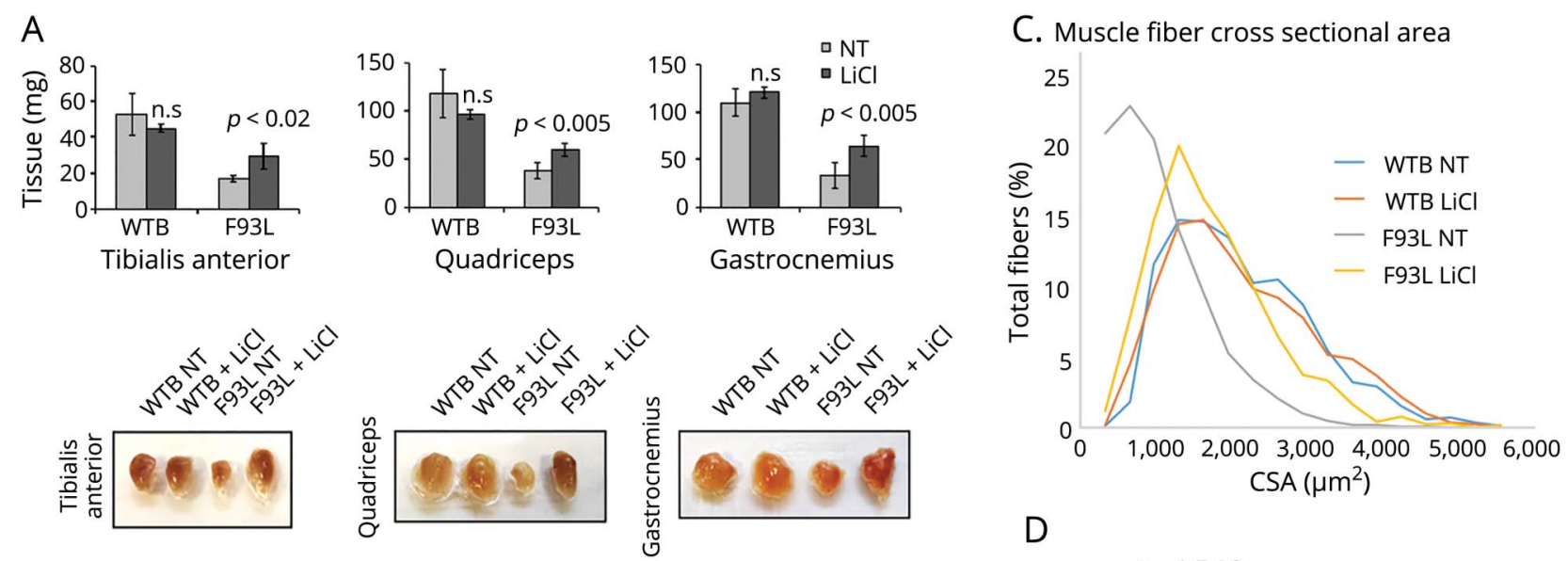

B
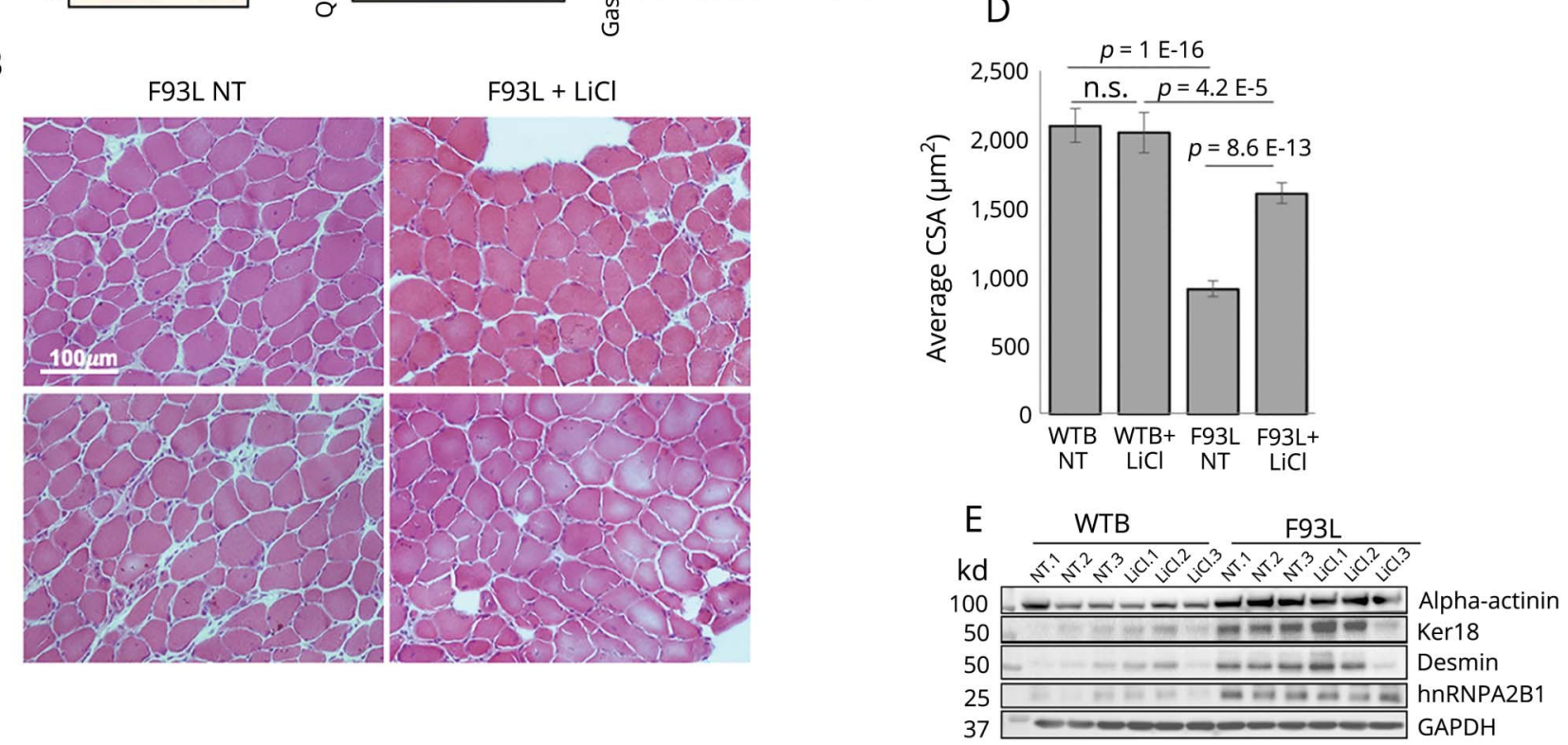

(A) Mass of selected muscles after 1 month of treatment. Note visible difference in the size of F93L muscles treated with LiCl. (B) H\&E staining of TA from $\mathrm{LiCl}$ treated or untreated F93L mice illustrating increased muscle fiber size and reduced fiber size variability. Two representative examples are provided from the tibialis anterior. (C) Quantitation of fiber CSA profile demonstrates an overall increase in the muscle fiber size after LiCl treatment in $\mathrm{F} 93 \mathrm{~L}$ mice and no change in LiCl-treated control mice. (D) Average muscle fiber cross-sectional area of LiCl-treated F93L mice significantly improves but does not reach control levels. LiCl does not alter the muscle fiber size of control mice. Error bars from A and D represent the standard error. (E) Western blot of skeletal muscle lysates in LiCl-treated and untreated mice illustrates no improvement in accumulated sarcomeric proteins or RNA-binding proteins in F93L mice. WT = wild type.

daily intraperitoneal injection for 1 month. Results were obtained from 4 mice per group. Two independent experiments were performed for a total of 8 mice per condition. We used a dose of $250 \mathrm{mg} / \mathrm{kg}$ body weight to mimic therapeutic serum levels in humans. ${ }^{21,22}$ Skeletal muscle function of LiCl-treated DNAJB6b-F93L mice, as measured by grip strength and inverted wire hang test, normalized to that of control mice over the course of the month (figure 4B). The mass and visible size of selected muscles and muscle fiber CSA were significantly increased in DNAJB6b-F93L mice treated with $\mathrm{LiCl}$ (figure 5, A-D). Despite improvements in strength and muscle fiber size, western blot analyses of skeletal muscle lysates demonstrated no change in accumulated sarcomeric proteins or RNA-binding proteins seen with DNAJB6 mutations (figure 5E).

\section{Discussion}

This study demonstrates that DNAJB6's role in skeletal muscle involves not only sarcomeric protein quality control but also suppression of myogenic signaling pathways important for myoblast differentiation, myotube fusion, skeletal muscle hypertrophy, and regeneration. Many other skeletal muscle chaperones also have dual roles in protein quality control and modulation of signaling pathways. The co-chaperone BAG3 facilitates autophagic sorting of damaged filamin to lysosomes while also engaging in YAP/TAZ mechanotransduction signaling. ${ }^{23} \alpha \beta$-crystallin not only functions as a desmin chaperone at the $\mathrm{Z}$ disc but also modulates NF- $\kappa \beta$ and TGF- $\beta 2$ signaling. ${ }^{24,25}$ HSP70 and HSP90 not only play key roles in myofibrillogenesis but also act 
as circulating cachexins by activating the $\mathrm{p} 38 \beta-\mathrm{MAPK}-\mathrm{C} / \mathrm{EBP} \beta$ catabolic signaling pathway. ${ }^{26}$ Although these dual functions may initially seem unrelated, regulation of protein synthesis is central to both these stress signaling pathways and maintaining balanced protein homeostasis. It is therefore not surprising to find chaperones that coordinate protein quality control with signaling pathways regulating protein synthesis.

Our comparisons between DNAJB6 KO and dominant LGMD1D models facilitated many interesting observations of DNAJB6's dual roles in skeletal muscle. For instance, $\mathrm{KO}$ of DNAJB6 in myoblasts and myotubes recapitulated the myofibrillar disorganization and accumulation of sarcomeric proteins seen in LGMD1D patients and animal models. ${ }^{3,8}$ In general, protein aggregation in myopathies may occur from mutations causing a protein itself to misfold and aggregate (e.g., desmin) or from mutations in protein quality control machinery (e.g., $\alpha \beta$-crystallin) causing other proteins to aggregate (desmin). With DNAJB6, the absence of sarcomeric chaperone activity could explain the altered myofibrillar assembly and accumulation of sarcomeric proteins in KO cells. Other DNAJB6 KO models have similarly resulted in aggregation of client proteins. ${ }^{27,28}$ Because LGMD1D is not due to a KO or loss of DNAJB6, one could speculate that the vacuolar and aggregate myopathology seen with disease mutations results from a dominant negative effect on DNAJB6's sarcomeric chaperone activities. Lending support to this theory, mutations in $V C P, B A G 3$, and $C R Y A B$ are also thought to cause myopathies with vacuoles and aggregates from a dominant negative mechanism. ${ }^{29-31}$

However, several findings in this study do not fit this theory. Specifically, dominant mutations and absence of DNAJB6 had opposite effects on GSK3 $\beta$ phosphorylation status and downstream myogenic signaling pathways. We found an increased size of DNAJB6 KO myotubes owing to an enhanced fusion index. This may be related to impaired dephosphorylation of GSK3 $\beta$ $\mathrm{P}($ ser-9) and derepression of downstream myogenic signaling pathways such as $\beta$-catenin and NFATc3 ${ }^{9-12,32}$ Contrary to KO cells, dominant DNAJB6 mutations were associated with an enhanced dephosphorylation of GSK3 $\beta-\mathrm{P}($ ser-9) and suppressed $\beta$-catenin and NFATc3 transcriptional activity. Although DNAJB6 is known to chaperone the dephosphorylation of GSK3 $3-P($ ser-9) to maintain it in an active state, the exact mechanism linking DNAJB6 disease mutations with enhanced GSK3 $\beta$-P(ser-9) dephosphorylation is not clear. One could speculate that it may be related to a gain of function from increased stability of the mutant DNAJB6 protein; however, further studies are needed. ${ }^{4,8}$

As DNAJB6 appears to have multiple functions within skeletal muscle, it is not surprising that mutations may cause disease through multiple mechanisms. $\mathrm{LiCl}$ is well suited to address alterations in both GSK3 $\beta$ signaling and protein aggregation. It acts as a competitive inhibitor of the adenosine triphosphate-magnesium-dependent catalytic activity of
GSK $3 \beta$ and may also act indirectly through enhanced phosphorylation of GSK3 $\beta .^{33}$ Although GSK3 $\beta$ activity suppresses myogenesis and blunts skeletal muscle regeneration, it has also been linked to formation of aggregates in several disorders, making GSK3 $\beta$ inhibition a good strategy for LGMD1D treatment. ${ }^{34,35} \mathrm{LiCl}$ also stimulates autophagy independent of GSK3 $\beta$, which may benefit LGMD1D further. ${ }^{36}$ Given LiCl's dual impact on GSK3 $\beta$ and autophagy, many have used it to treat in vivo models of neurologic disorders with protein aggregate pathology and GSK $3 \beta$ dysfunction, such as Huntington disease, Alzheimer disease, SOD1 amyotrophic lateral sclerosis, Parkinson disease, and inclusion body myositis. ${ }^{33-35,37-40}$ In addition to showing therapeutic efficacy in these animal models, $\mathrm{LiCl}$ improved biochemical markers of disease and histopathologic evidence of aggregates. ${ }^{34,37-40}$ These previous studies raise the possibility that the significant improvement of LGMD1D mice treated with $\mathrm{LiCl}$ was due to enhanced autophagy and clearance of accumulated sarcomeric proteins. Of interest, the accumulations of sarcomeric and RNA binding proteins in mutant mouse muscle were not altered by $\mathrm{LiCl}$ treatment (figure $5 E$ ). This lack of improvement may simply be due to pathologic changes lagging behind functional improvements. However, it may actually suggest that LGMD1D pathogenesis is due not only to DNAJB6 dysfunction in protein quality control but also to GSK3 $\beta$-related signaling pathways. Further studies are required to clarify, however, that $\mathrm{LiCl}$ may be an ideal therapeutic option for LGMD1D.

\section{Study funding}

This work was supported by NIH AG031867 (C.C.W.), AG042095 (C.C.W.), and AR068797 (C.C.W. and H.L.T.) and the Muscular Dystrophy Association (C.C.W.).

\section{Disclosure}

A.R. Findlay has received foundation/society research support from the American Academy of Neurology. R. Bengoechea has served on the editorial board of BioMed Central Neuroscience. S.K. Pittman reports no disclosures. T.-F. Chou has served on the editorial board of the Journal of Cancer Sciences; holds patents in Methods and Compositions for Inhibition of the Transitional Endoplasmic Reticulum ATPase; and has received government funding from the NIH. H.L. True has served on the editorial board of PLOS Pathogens and has received government funding from the NIH. C.C. Weihl has served on advisory boards of Novartis, Acceleron, and Sarepta; has served on the editorial board of Neuromuscular Disorders; has received government funding from the NIH; and has received foundation/society research support from the Muscular Dystrophy Association and the Myositis Association. Disclosures available: Neurology.org/NG.

\section{Publication history}

Received by Neurology: Genetics October 19, 2018. Accepted in final form February 4, 2019. 
Appendix Author contributions

\begin{tabular}{|c|c|c|c|}
\hline Name & Location & Role & Contribution \\
\hline $\begin{array}{l}\text { Andrew R. } \\
\text { Findlay, MD }\end{array}$ & $\begin{array}{l}\text { Washington } \\
\text { University St. } \\
\text { Louis }\end{array}$ & Author & $\begin{array}{l}\text { Design and conceptualization } \\
\text { of the study, acquisition of } \\
\text { data, interpretation of data, } \\
\text { writing of the manuscript, and } \\
\text { revision of the manuscript for } \\
\text { intellectual content. }\end{array}$ \\
\hline $\begin{array}{l}\text { Rocio } \\
\text { Bengoecha, } \\
\text { PhD }\end{array}$ & $\begin{array}{l}\text { Washington } \\
\text { University St. } \\
\text { Louis }\end{array}$ & Author & $\begin{array}{l}\text { Acquisition of data and } \\
\text { revision of the manuscript for } \\
\text { intellectual content. }\end{array}$ \\
\hline $\begin{array}{l}\text { Sara K. } \\
\text { Pittman, BS }\end{array}$ & $\begin{array}{l}\text { Washington } \\
\text { University St. } \\
\text { Louis }\end{array}$ & Author & Acquisition of data. \\
\hline $\begin{array}{l}\text { Tsui-Fen } \\
\text { Chou, PhD }\end{array}$ & $\begin{array}{l}\text { Harbor- } \\
\text { UCLA } \\
\text { Medical } \\
\text { Center }\end{array}$ & Author & $\begin{array}{l}\text { Acquisition of data, } \\
\text { interpretation of data, and } \\
\text { revision of the manuscript for } \\
\text { intellectual content. }\end{array}$ \\
\hline $\begin{array}{l}\text { Heather L. } \\
\text { True, PhD }\end{array}$ & $\begin{array}{l}\text { Washington } \\
\text { University St. } \\
\text { Louis }\end{array}$ & Author & $\begin{array}{l}\text { Revision of the manuscript for } \\
\text { intellectual content. }\end{array}$ \\
\hline $\begin{array}{l}\text { Conrad C. } \\
\text { Weihl, MD, } \\
\text { PhD }\end{array}$ & $\begin{array}{l}\text { Washington } \\
\text { University St. } \\
\text { Louis }\end{array}$ & Author & $\begin{array}{l}\text { Design and conceptualization } \\
\text { of the study, interpretation of } \\
\text { data, and revision of the } \\
\text { manuscript for intellectual } \\
\text { content. }\end{array}$ \\
\hline
\end{tabular}

\section{References}

1. Smith DA, Carland CR, Guo Y, Bernstein SI. Getting folded: chaperone proteins in muscle development, maintenance and disease. Anat Rec (Hoboken) 2014;297:1637-1649.

2. Harms MB, Sommerville RB, Allred P, et al. Exome sequencing reveals DNAJB6 mutations in dominantly-inherited myopathy. Ann Neurol 2012;71: 407-416.

3. Sandell S, Huovinen S, Palmio J, et al. Diagnostically important muscle pathology in DNAJB6 mutated LGMD1D. Acta Neuropathol Commun 2016;4:9.

4. Sarparanta J, Jonson PH, Golzio C, et al. Mutations affecting the cytoplasmic functions of the co-chaperone DNAJB6 cause limb-girdle muscular dystrophy. Nat Genet 2012;44:450-452, S1-2.

5. Straub V, Murphy A, Udd B. LGMD workshop study group. 229th ENMC international workshop: Limb girdle muscular dystrophies-Nomenclature and reformed classification Naarden, the Netherlands, 17-19 March 2017. Neuromuscul Disord 2018;28:702-710.

6. Kampinga HH, Craig EA. The HSP70 chaperone machinery: J proteins as drivers of functional specificity. Nat Rev Mol Cell Biol 2010;11:579-592.

7. Seki N, Hattori A, Hayashi A, Kozuma S, Miyajima N, Saito T. Cloning, tissue expression, and chromosomal assignment of human MRJ gene for a member of the DNAJ protein family. J Hum Genet 1999;44:185-189.

8. Bengoechea R, Pittman SK, Tuck EP, True HL, Weihl CC. Myofibrillar disruption and RNA-binding protein aggregation in a mouse model of limb-girdle muscular dystrophy 1D. Hum Mol Genet 2015;24:6588-6602.

9. Meng E, Shevde LA, Samant RS. Emerging roles and underlying molecular mechanisms of DNAJB6 in cancer. Oncotarget 2016;7:53984-53996.

10. Mitra A, Menezes ME, Pannell LK, et al. DNAJB6 chaperones PP2A mediated dephosphorylation of GSK $3 \beta$ to downregulate $\beta$-catenin transcription target, osteopontin. Oncogene 2012;31:4472-4483.

11. Mitra A, Menezes ME, Shevde LA, Samant RS. DNAJB6 induces degradation of betacatenin and causes partial reversal of mesenchymal phenotype. J Biol Chem 2010;285: 24686-24694.

12. Menezes ME, Mitra A, Shevde LA, Samant RS. DNAJB6 governs a novel regulatory loop determining $W n t / \beta$-catenin signalling activity. Biochem J 2012;444:573-580.

13. Suzuki A, Pelikan RC, Iwata J. WNT/ $\beta$-Catenin signaling regulates multiple steps of myogenesis by regulating step-specific targets. Mol Cell Biol 2015;35:1763-1776.
14. van der Velden JL, Schols AM, Willems J, Kelders MC, Langen RC. Glycogen synthase kinase 3 suppresses myogenic differentiation through negative regulation of NFATc3. J Biol Chem 2008;283:358-366.

15. Vyas DR, Spangenburg EE, Abraha TW, Childs TE, Booth FW. GSK-3beta negatively regulates skeletal myotube hypertrophy. Am J Physiol Cell Physiol 2002;283: C545-C551.

16. Dai YS, Xu J, Molkentin JD. The DnaJ-related factor Mrj interacts with nuclear factor of activated $\mathrm{T}$ cells $\mathrm{c} 3$ and mediates transcriptional repression through class II histone deacetylase recruitment. Mol Cell Biol 2005;25:9936-9948.

17. Kato M, Chou TF, Yu CZ, DeModena J, Sternberg PW. LINKIN, a new transmembrane protein necessary for cell adhesion. Elife 2014;3:e04449.

18. Sapir A, Tsur A, Koorman T, et al. Controlled sumoylation of the mevalonate pathway enzyme HMGS-1 regulates metabolism during aging. Proc Natl Acad Sci USA 2014; 111:E3880-E3889.

19. Kim HJ, Kim NC, Wang YD, et al. Mutations in prion-like domains in hnRNPA2B1 and hnRNPAl cause multisystem proteinopathy and ALS. Nature 2013;495: 467-473.

20. Pansters NA, Schols AM, Verhees KJ, et al. Muscle-specific GSK-3 $\beta$ ablation accelerates regeneration of disuse-atrophied skeletal muscle. Biochim Biophys Acta 2015, 1852:490-506.

21. Patel NC, DelBello MP, Bryan HS, et al. Open-label lithium for the treatment of adolescents with bipolar depression. J Am Acad Child Adolesc Psychiatry 2006;45: 289-297.

22. Nair $A B$, Jacob $S$. A simple practice guide for dose conversion between animals and human. J Basic Clin Pharm 2016;7:27-31.

23. Ulbricht A, Eppler FJ, Tapia VE, et al. Cellular mechanotransduction relies on tensioninduced and chaperone-assisted autophagy. Curr Biol 2013;23:430-435.

24. Adhikari AS, Singh BN, Rao KS, Rao CM. aB-crystallin, a small heat shock protein, modulates NF- $\mathrm{kB}$ activity in a phosphorylation-dependent manner and protects muscle myoblasts from TNF- $\alpha$ induced cytotoxicity. Biochim Biophys 2011;1813: $1532-1542$.

25. Nahomi RB, Pantcheva M, Nagaraj RH. $\alpha$ B-Crystallin is Essential for the TGF- $\beta 2$ mediated Epithelial to Mesenchymal Transition of Lens Epithelial Cells. Biochem J 2016;473:1455-1469.

26. Zhang G, Liu Z, Ding H, et al. Tumor induces muscle wasting in mice through releasing extracellular Hsp70 and Hsp90. Nat Commun 2017;8:589.

27. Watson ED, Geary-Joo C, Hughes M, Cross JC. The Mrj co-chaperone mediates keratin turnover and prevents the formation of toxic inclusion bodies in trophoblast cells of the placenta. Development 2007;134:1809-1817.

28. Aprile FA, Källstig E, Limorenko G, Vendruscolo M, Ron D, Hansen C. The molecular chaperones DNAJB6 and Hsp70 cooperate to suppress $\alpha$-synuclein aggregation. Sci Rep 2017;7:9039.

29. Kitami MI, Kitami T, Nagahama M, et al. Dominant-negative effect of mutant valosincontaining protein in aggresome formation. FEBS Lett 2006;580:474-478.

30. Myers VD, McClung JM, Wang J, et al. The multifunctional protein BAG3: A novel therapeutic target in cardiovascular disease. JACC Basic Transl Sci 2018;3: $122-131$

31. Selcen D, Engel AG. Myofibrillar myopathy caused by novel dominant negative $\alpha \mathrm{B}$ crystallin mutations. Ann Neurol 2003;54:804-810.

32. Mitra A, Fillmore RA, Metge BJ, et al. Large isoform of MRJ (DNAJB6) reduces malignant activity of breast cancer. Breast Cancer Res 2008;10:R22.

33. Chuang DM, Wang Z, Chiu CT. GSK-3 as a target for lithium-induced neuroprotection against excitotoxicity in neuronal cultures and animal models of ischemic stroke. Front Mol Neurosci 2011;4:15.

34. Kitazawa M, Trinh DN, LaFerla FM. Inflammation induces tau pathology in inclusion body myositis model via glycogen synthase kinase-3 $\beta$. Ann Neurol 2008;64 $15-24$.

35. Beurel E, Grieco SF, Jope RS. Glycogen synthase kinase-3 (GSK3): regulation, actions, and diseases. Pharmacol Ther 2015;148:114-131.

36. Motoi Y, Shimada K, Ishiguro K, Hattori N. Lithium and autophagy. ACS Chem Neurosci 2014;5:434-442.

37. Pouladi MA, Brillaud E, Xie Y, et al. NP03, a novel low-dose lithium formulation, is neuroprotective in the YAC128 mouse model of Huntington disease. Neurobiol Dis 2012;48:282-289.

38. Zhang $\mathrm{X}$, Heng $\mathrm{X}, \mathrm{Li} \mathrm{T}$, et al. Long-term treatment with lithium alleviates memory deficits and reduces amyloid- $\beta$ production in an aged Alzheimer's disease transgenic mouse model. J Alzheimers Dis 2011;24:739-749.

39. Fornai $\mathrm{F}$, Longone $\mathrm{P}$, Cafaro L, et al. Lithium delays progression of amyotrophic lateral sclerosis. Proc Natl Acad Sci USA 2008;105:2052-2057.

40. Kim Y-H, Rane A, Lussier S, Andersen JK. Lithium protects against oxidative stressmediated cell death in $\alpha$-synuclein-overexpressing in vitro and in vivo models of Parkinson's disease. J Neurosci Res 2011;89:1666-1675. 


\section{Neurology

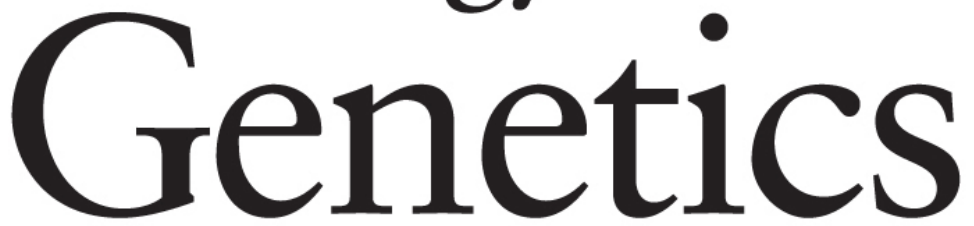

\section{Lithium chloride corrects weakness and myopathology in a preclinical model of LGMD1D}

Andrew R. Findlay, Rocio Bengoechea, Sara K. Pittman, et al.

Neurol Genet 2019;5;

DOI 10.1212/NXG.0000000000000318

This information is current as of April 19, 2019

\section{Updated Information \& Services}

References

Citations

Subspecialty Collections

Permissions \& Licensing

Reprints including high resolution figures, can be found at: http://ng.neurology.org/content/5/2/e318.full.html

This article cites 40 articles, 9 of which you can access for free at: http://ng.neurology.org/content/5/2/e318.full.html\#\#ref-list-1

This article has been cited by 3 HighWire-hosted articles: http://ng.neurology.org/content/5/2/e318.full.html\#\#otherarticles

This article, along with others on similar topics, appears in the following collection(s):

\section{All Neuromuscular Disease}

http://ng.neurology.org//cgi/collection/all_neuromuscular_disease Muscle disease

http://ng.neurology.org//cgi/collection/muscle_disease

Information about reproducing this article in parts (figures,tables) or in its entirety can be found online at:

http://ng.neurology.org/misc/about.xhtml\#permissions

Information about ordering reprints can be found online: http://ng.neurology.org/misc/addir.xhtml\#reprintsus

Neurol Genet is an official journal of the American Academy of Neurology. Published since April 2015, it is an open-access, online-only, continuous publication journal. Copyright Copyright ( 2019 The Author(s). Published by Wolters Kluwer Health, Inc. on behalf of the American Academy of Neurology.. All rights reserved. Online ISSN: 2376-7839.

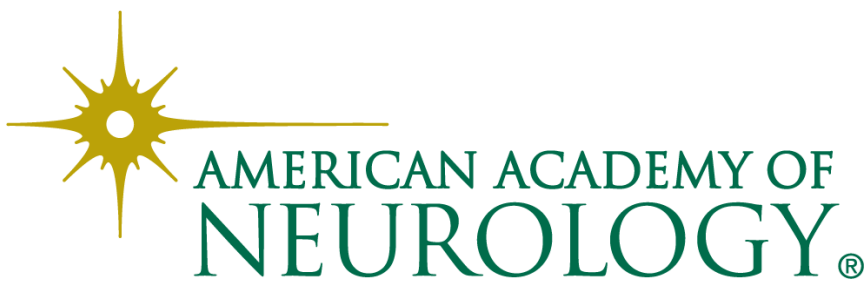

